\title{
Seed traits, germination pattern and seedling vigour in Antiaris toxicaria (Pers.) Lesch., a rare plant species of Western ghats
}

\author{
A. B. Mirgal ${ }^{1}$, Rajesh P. Gunaga ${ }^{2 *}$, and C. B. Salunkhe ${ }^{3}$ \\ ${ }^{1}$ College of Forestry, Dr. B.S. Konkan Krishi Vidyapeeth, Dapoli-415712 (Maharashtra), INDIA \\ ${ }^{2}$ College of Forestry, ACHF, Navsari Agricultural University, Navsari-396450 (Gujarat), INDIA \\ ${ }^{3}$ Krishna Mahavidyalaya, Rethare Bk., Karad-415108 (Maharashtra), INDIA \\ *Corresponding author. E-mail: rpgunaga@gmail.com
}

Received: March 08, 2015; Revised received: July 01, 2016; Accepted: August 30, 2016

\begin{abstract}
Antiaris toxicaria (Pers.) Lesch. is one of the species of ecological importance distributed in Western Ghats and other parts. This species is considered as one of the threatened species and it needs conservation. The information on fruit and seed trait variation and germination attributes are scanty. Such database is useful for afforestation programme as well as for augmentation of rare plant species in their natural habitat. For the present study, 10 open pollinated trees distributed in Devade forest of Sakharpa were marked. April month was the peak fruiting period and healthy fruits were collected from the ground. Fruit and seed traits were found to be varied significantly among trees, where fruit length ranged from 21.50 to $24.71 \mathrm{~mm}$ and fruit weight ranged from 3.64 to $4.07 \mathrm{~g}$. Similarly, seeds length (14.01 -15.09 mm), seed thickness $(12.15-13.04 \mathrm{~mm})$ and seed weight $(1.20-1.57 \mathrm{~g})$ also showed significant variation among 10 trees. Field observation showed that there was a poor regeneration in this species at studied site. Therefore, germination study was conducted at nursery condition by imposing several pretreatments. Among eight treatments including control, soaking seeds in water for $24 \mathrm{hrs}\left(\mathrm{T}_{2}\right)$ resulted in better germination of $38.0 \%$ as compared to others. In $\mathrm{T}_{2}$ seed germination started at 16 days after sowing and completed within 42 days. Potting mixture of red soil with saw dust in 30:70 ratio improved seed germination about $20 \%$ as compared to red soil media.
\end{abstract}

Keywords: Antiaris toxicaria, Conservation, Germination, Seed traits, Seedling vigour

\section{INTRODUCTION}

Antiaris toxicaria (Pers.) Lesch. is one of the climax forest species of Western Ghats and is scatterly distributed in semi-evergreen to evergreen forests of Kerala, Karnataka, Goa and Maharashtra. Tree occupies the top canopy in the natural forest and grows up to $50 \mathrm{~m}$ height with buttressed trunk. Seeds, leaves and barks have got medicinal properties and are used as astringent. Moreover, seeds have anti-dysentric properties. Antiarin is cardiac glycosides recovered from milky latex of this species (Kopp et al., 1992). Milky latex of this species is poisonous in nature (Ravikumar and Sankar, 2009). In ancient days, this sap was used as poison for arrows, darts and blow-darts.

The survey shows that there are few scattered huge trees in the forests of southern Maharashtra namely, Devade and Marleshwar; however, in other forests of Zarye, Godagewadi, Sadavali, Dhankal, Ozarde, Phansad, Birmani and Devole, one or two isolated individuals were marked and absolutely no regeneration was recorded in many of the forests (Mirgal et al., 2013). This shows that this species needs conservation attention. Further, tree domestication can be attempted for effective utilization of species under different landuse systems such as social forest, urban forest, agroforest plantation as well as augmentation of this species in natural forests. However, basic information on fruit and seed biology, germinability and seedling growth of this species is scanty. Therefore, the present study was undertaken with the aim to a.) characterize fruit and seed, b) identify suitable pre-sowing treatment for better germination and c). asses the seedling vigour in this species.

\section{MATERIALS AND METHODS}

A. toxicaria is scatterly distributed in Konkan region of Maharashtra. Usually one or two isolated big trees are located in different climax forests of Konkan. Devade forest of Sakharpa of Ratnagiri is one of the forests identified had more trees of 17 adults. The forest is located at $16^{\circ} 55^{\prime} 13^{\prime \prime} \mathrm{N}$ latitude and $73^{\circ} 46^{\prime} 45^{\prime \prime} \mathrm{E}$ longitude. Among these, only 10 trees $\left(\mathrm{ATDT}_{1}\right.$ to $\mathrm{ATDT}_{10}$ ), which bear fruits, were marked for fruit collection. Healthy fruits were collected tree wise during end of April 2012 and they were shifted to laboratory for further observation.

The present study was carried out in the laboratory and forest nursery of College of Forestry, Dr. B.S. Konkan Krishi Vidyapeeth, Dapoli, Ratnagiri district of Maharashtra. During the study period, these trees pro- 
duced poor fruit set and hence, number of fruit/seed samples was limited to 50 samples. For fruit and seed characterization, only 50 randomly selected healthy fruits per tree were used (Gunaga and Vasudeva, 2009). Observation on fruit and seed traits in terms of weight $(\mathrm{g})$, length $(\mathrm{mm})$, thickness $(\mathrm{mm})$ and pulp content $(\mathrm{g})$ was recorded.

For germination trial, bulk seeds collected from Devade forest were used. Fresh bulk fruits collected were depulped and seeds were extracted. In the germination trial, following eight different pre-sowing treatments including control were imposed during May 2012.

\begin{tabular}{ll}
\hline $\begin{array}{l}\text { Treat- } \\
\text { ments }\end{array}$ & Details of pre-sowing treatments imposed \\
\hline $\mathrm{T}_{1}$ & Control \\
$\mathrm{T}_{2}$ & Soaking seeds in water for $24 \mathrm{hrs}$ \\
$\mathrm{T}_{3}$ & Soaking seeds in water for $48 \mathrm{hrs}$ \\
$\mathrm{T}_{4}$ & Soaking seeds in luke warm water for $24 \mathrm{hrs}$ \\
$\mathrm{T}_{5}$ & Soaking seeds in GA3 @ $100 \mathrm{ppm}$ solution for 6 \\
& hrs \\
$\mathrm{T}_{6}$ & Soaking seeds in GA3 @ $300 \mathrm{ppm}$ solution for 6 \\
& hrs \\
$\mathrm{T}_{7}$ & Soaking seeds in GA3 @ 500 ppm solution for 6 \\
& hrs \\
$\mathrm{T}_{8}$ & Soaking seeds in cow dung slurry for three days \\
\hline
\end{tabular}

Germination trial was undertaken under mist chamber of College of Forestry, Dapoli. For each treatment, four replications containing 50 seeds each were sown on nursery bed. Daily germination count was made up to 120 days from the date of sowing. Furthermore, seed germination was also tested two growing media, where red soil $\left(T_{1}\right)$ was considered as control and red soil with saw dust in ratio of 30:70 $\left(\mathrm{T}_{2}\right)$ was considered as treatment.

In order to study the growth pattern at nursery, 25 seedlings were raised separately in polybags containing red soil. Growth observations like seedling height, basal diameter and number of leaves were recorded up to six months. Further, 10 randomly selected seedlings of six months old were used to record biomass attributes like fresh and dry weight of shoot, leaf and root. Data were compiled and subjected to statistical analysis following simple CRD using mstat-C statistical software and ANOVA was constructed as per the procedure suggested by Gomez and Gomez (1984). For seedling growth and biomass traits, simple mean and standard deviation were calculated and used in interpretation of data.

\section{RESULTS AND DISCUSSION}

Result showed that there was a significant variation among 10 different trees for various fruit and seed traits (Table 1). Fruit length varied from 21.50 $\left(\mathrm{ATDT}_{9}\right)$ to $24.71 \mathrm{~mm}\left(\mathrm{ATDT}_{1}\right)$ with an overall mean $23.67 \mathrm{~mm}$, whereas fruit thickness ranged between $18.36\left(\mathrm{ATDT}_{10}\right)$ and $19.75 \mathrm{~mm}\left(\mathrm{ATDT}_{4}\right)$. Fruit weight varied from $3.64\left(\mathrm{ATDT}_{10}\right)$ to $4.07 \mathrm{~g}\left(\mathrm{ATDT}_{1}\right.$ and $\mathrm{ATDT}_{9}$ ) with an overall mean of $3.88 \mathrm{~g}$ (Table 1 ). Seeds collected from tree bearing no. ATDT 10 showed the lowest seed length $(14.01 \mathrm{~mm})$, seed thickness $(12.15 \mathrm{~mm})$ and seed weight $(1.20 \mathrm{~g})$, whereas tree no. $\mathrm{ATDT}_{7}$ showed maximum seed length of $15.09 \mathrm{~mm}$, thickness of $13.04 \mathrm{~mm}$ and seed weight of $1.57 \mathrm{~g}$ (Table 1). Pulp weight varied significantly among 10 trees and it varied from $2.11\left(\mathrm{ATDT}_{7}\right)$ to $2.79 \mathrm{~g}\left(\mathrm{ATDT}_{5}\right)$ with mean pulp weight of $2.55 \mathrm{~g}$ (Table 1). In the present study, fresh weight, dry weight and seed moisture content of bulk samples were recorded as follows: $5.07 \mathrm{~g} \pm 0.63$, $3.31 \mathrm{~g} \pm 0.38$ and $53.08 \% \pm 1.57$, respectively.

Pattern of seed germination among several pretreatments is depicted in fig.1. Seeds of A. toxicaria started germination within 16 days after sowing (DAS) in different treatments and took about 105 days to complete its germination. In control, initial germination was 14 per cent at 37 DAS and it was prolonged up to 105 DAS with 33 per cent germination. Among several pre-treatments, $\mathrm{T}_{2}$ (soaking seeds in water for $24 \mathrm{hrs}$ ) resulted in better germination of 38 per cent, followed by $\mathrm{T}_{6}$ (soaking seeds in GA3-300 ppm solution for $6 \mathrm{hrs}$ ) as compared to other pre-treatments. Interestingly, in $\mathrm{T}_{2}$ treatment, seed germination initiated during 16 DAS and completed its germination within 42 DAS (37\%; Fig. 1). Treatments such as $\mathrm{T}_{3}$, $\mathrm{T}_{4}, \mathrm{~T}_{5}, \mathrm{~T}_{7}$ and $\mathrm{T}_{8}$, infact, inhibited seed germination

Table 1. Variation in fruit and seed traits among different trees in A. toxicaria $(\mathrm{N}=50)$.

\begin{tabular}{|c|c|c|c|c|c|c|c|}
\hline \multirow[b]{2}{*}{ Trees } & \multicolumn{3}{|c|}{ Fruit traits } & \multicolumn{3}{|c|}{ Seed traits } & \multirow[b]{2}{*}{$\begin{array}{c}\text { Pulp } \\
\text { weight (g) }\end{array}$} \\
\hline & $\begin{array}{c}\text { Weight } \\
\text { (g) }\end{array}$ & $\begin{array}{c}\text { Length } \\
(\mathrm{mm})\end{array}$ & $\begin{array}{c}\text { Thickness } \\
\text { (mm) }\end{array}$ & $\begin{array}{c}\text { Weight } \\
\text { (g) }\end{array}$ & $\begin{array}{c}\text { Length } \\
(\mathrm{mm})\end{array}$ & $\begin{array}{c}\text { Thickness } \\
\text { (mm) }\end{array}$ & \\
\hline $\mathrm{ATDT}_{1}$ & 4.07 & 24.71 & 19.11 & 1.36 & 14.37 & 12.70 & 2.71 \\
\hline $\mathrm{ATDT}_{2}$ & 3.74 & 23.61 & 18.86 & 1.30 & 14.21 & 12.24 & 2.44 \\
\hline $\mathrm{ATDT}_{3}$ & 3.88 & 23.72 & 19.60 & 1.31 & 14.35 & 12.38 & 2.58 \\
\hline $\mathrm{ATDT}_{4}$ & 3.72 & 24.62 & 19.75 & 1.25 & 14.25 & 12.09 & 2.47 \\
\hline $\mathrm{ATDT}_{5}$ & 4.05 & 23.46 & 19.15 & 1.26 & 14.12 & 12.31 & 2.79 \\
\hline $\mathrm{ATDT}_{6}$ & 3.99 & 23.47 & 19.64 & 1.27 & 14.35 & 12.35 & 2.71 \\
\hline $\mathrm{ATDT}_{7}$ & 3.68 & 23.43 & 18.44 & 1.57 & 15.09 & 13.04 & 2.11 \\
\hline $\mathrm{ATDT}_{8}$ & 3.92 & 24.55 & 19.04 & 1.33 & 14.39 & 12.57 & 2.60 \\
\hline $\mathrm{ATDT}_{9}$ & 4.07 & 21.50 & 19.01 & 1.45 & 14.88 & 12.97 & 2.62 \\
\hline $\mathrm{ATDT}_{10}$ & 3.64 & 23.62 & 18.36 & 1.20 & 14.01 & 12.15 & 2.44 \\
\hline Grand Mean & 3.88 & 23.67 & 19.10 & 1.33 & 14.40 & 12.48 & 2.55 \\
\hline CD@5\% P & 0.35 & 1.60 & 1.19 & 0.19 & 0.76 & 0.65 & 0.35 \\
\hline
\end{tabular}


Table 2. Growth and biomass attributes of A. toxicaria at nursery level (Plant age $=6$ month).

\begin{tabular}{ll}
\hline Growth and Biomass Parameters & Mean \pm SD \\
\hline Plant height $(\mathrm{cm})$ & $25.96 \pm 4.30$ \\
Collar diameter $(\mathrm{mm})$ & $4.88 \pm 0.67$ \\
Root length $(\mathrm{cm})$ & $8.86 \pm 4.91$ \\
No. of leaves per plant & $8.5 \pm 1.51$ \\
Fresh weigh to Shoot $(\mathrm{g})$ & $1.61 \pm 0.49$ \\
Fresh weigh to Root $(\mathrm{g})$ & $2.59 \pm 1.79$ \\
Fresh weigh to leaves $(\mathrm{g})$ & $1.85 \pm 0.52$ \\
Total fresh weight of seedling $(\mathrm{g})$ & $6.06 \pm 2.65$ \\
Dry weigh to Shoot $(\mathrm{g})$ & $0.64 \pm 0.25$ \\
Dry weigh to Root $(\mathrm{g})$ & $0.83 \pm 0.58$ \\
Dry weigh to leaves $(\mathrm{g})$ & $0.59 \pm 0.18$ \\
Total dry weight of seedling $(\mathrm{g})$ & $2.06 \pm 0.94$ \\
\hline
\end{tabular}

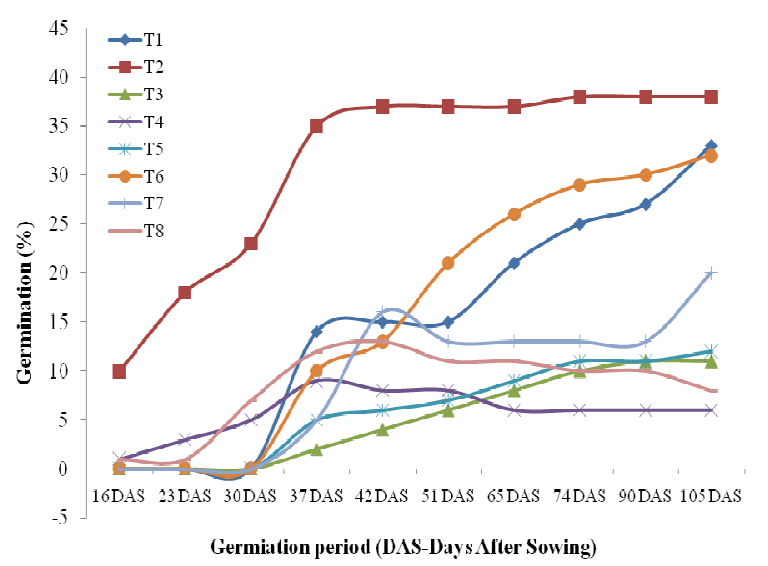

Fig. 1. Influence of seed treatments on seed germination in A. toxicaria $\left(T_{1^{-}}\right.$Control; $T_{2^{-}}$-soaking seeds in water $24 \mathrm{hrs} ; T_{3^{-}}$ soaking seeds in normal water $48 \mathrm{hrs}, T_{4^{-}}$soaking seeds in luke warm water 24 hrs; $T_{5^{-}}$soaking seeds in $G A_{3} @ 100$ ppm solution for 6 hrs; $T_{6}$ - soaking seeds in $G_{3} @ 300 p p m$ solution for 6 hrs; $T_{7}$ - soaking seeds in $\mathrm{GA}_{3} @ 500$ ppm solution for 6 hrs; $T_{8}$ - soaking seeds in cow dung slurry for 3 days).

(Fig. 1). Influence of red soil $\left(\mathrm{T}_{1}\right)$ and red soil with saw dust in ratio of 30:70 $\left(\mathrm{T}_{2}\right)$ on seed germination was studied. Media containing soil and saw dust $\left(\mathrm{T}_{2}\right)$ showed early germination as well as highest germination as compared to red soil (Fig. 2).

Details of growth and biomass of seedlings at the age of six months in the nursery are given in table 2 . On an average, six months old plant grows up to the height of about $26 \mathrm{~cm}$ with collar diameter of $4.88 \mathrm{~mm}$ and root length of $8.86 \mathrm{~cm}$. Total dry biomass of seedling $($ shoot + root + leaf $)$ was $2.06 \pm 0.94 \mathrm{~g}$ and it varied among sampled seedlings from 1.05 to $3.91 \mathrm{~g}$ per plant. The overall fresh weight of leaf, shoot and root was $1.85 \pm 0.52,1.61 \pm 0.49$ and $2.59 \pm 1.79 \mathrm{~g}$, respectively (Table 2). Dry weight of leaf, shoot and root of A. toxicaria seedlings recorded at 6 months age was $0.59,0.64$ and $0.83 \mathrm{~g}$, respectively.

A. toxicaria is monoecious tree species that produce crowded male flowers and solitary female flower and pollinated by tiny insects. It blooms during October to

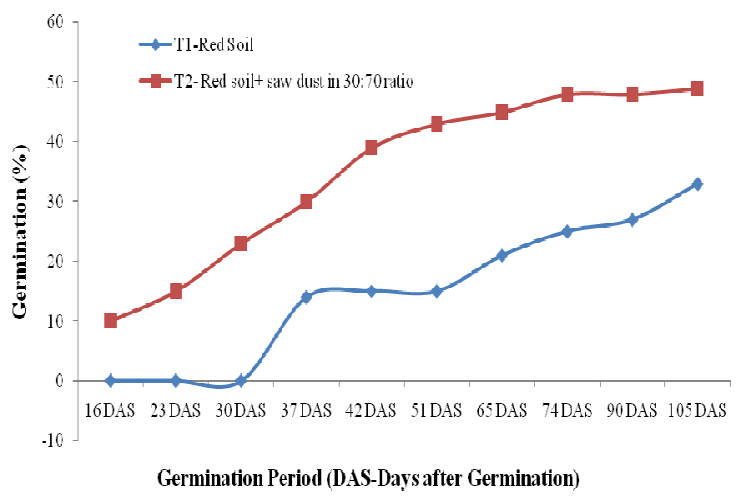

Fig. 2. Influence of potting media on seed germination in A. toxicaria.

January and fruit fall occurs during April to June. It was recorded that fruits were velvet red in colour containing single whitish seeds. The present study has increased understanding of the basic history traits like seed biology and seedling vigour of this species. Result shows that there was intra-population variation in fruit and seed characters in A. toxicaria indicating the scope for genetic improvement of this species through half-sib family selection. Vasudeva et al. (2005) studied tree to tree variation in reproductive traits and germination attributes in Dysoxylum malabaricum. Further, half-sib family variation for seedling vigour was also recorded. Similarly, Gunaga and Vasudeva (2009) reported significant variation in seedling vigour among half-sib families of Mammea suriga at nursery stage. Several authors stressed upon the importance of seed and seedling ecology on conservation and genetic improvement of different species like Dysoxylum binectariferum (Gunaga et al., 2008), Nothapodytes nimmoniana (Hareesh et al., 2008), Calophyllum inophyllum (Gunaga et al., 2011) and Garcinia talbotii (Bansude, 2013). Therefore, the information provided in the study may be useful for further improvement, conservation and sustainable management of this species.

\section{Conclusion}

It is concluded that tree to tree variation in fruit and seed traits has been recorded in this species. Fruit weight (3.64 to $4.07 \mathrm{~g}$ ) and seed weight (1.2 to $1.57 \mathrm{~g}$ ) including other traits varied significantly among 10 trees indicating lot scope for further tree selection and it needs detailed study. Based seed traits, tree no. $\mathrm{T}_{7}$ performed better and may be used for large scale seed collection. Germination of this species is improved through presowing treatments viz., soaking seeds in water for $24 \mathrm{hrs}\left(\mathrm{T}_{2}\right)$ and soaking seeds in $\mathrm{GA}_{3}-300$ ppm solution for $6 \mathrm{hrs}\left(\mathrm{T}_{6}\right)$. Therefore, $\mathrm{T}_{2}$ treatment is suggested for large scale propagation, infact, this treatment is also cheaper. Potting mixture containing red soil and saw dust in the ratio of 70:30 enhanced seed germination than red soil alone, hence, mixture of red- 
soil and saw dust at 70:30 part is suggested for further enhancement of seed germination in Nursery.

\section{REFERENCES}

Bansude, A.A. (2013). Characterization of seed, germination and seedling vigour in Garcinia talbotii. M.Sc. thesis submitted to Dr. B.S. Konkan Krishi Vidyapeeth, Dapoli, Maharashtra, India, pp. 153.

Gomez, K.A. and Gomez, A.A. (1984). Statistical Procedures for Agricultural Research (2 ed.). Published by John Wiley and Sons, New York, pp. 680.

Gunaga, R.P. and Vasudeva, R. (2009). Seed traits and halfsib family variation for seed germination and early seedling vigour in Suragi (Mammea suriga), an important aromatic tree species of the Western Ghats. J. NonTimber Forest Products, 16(4): 285-290.

Gunaga, R.P., Manjunath, A.V. and R. Vasudeva (2008). Variation for Seed Traits and Germination in Dysoxylum binectariferum, an important medicinal resource of the Western Ghats. In: Forest, Medicinal Plants and People, College of Forestry, Sirsi, Karnataka, p. 100.

Gunaga, R.P., Smita, D.A., Ramesh V.G., Rane, A.D., Narkhede, S.S., Bhave, S.G. and Patwardhan, A. (2011). Intrapopulation variation in seed traits and seedling attributes in Calophyllum inophyllum Linn.: an important forest re- source of coastal region. In: Proceedings of national seminar on forest resources: diversity, utilization and conservation held at UAS Bangalore, pp. 21-24.

Hareesh, T.S., R. P. Gunaga, Vasudeva, R., Shivanna, K.R., Uma Shaanker, R. and Gladwin Joseph (2008). Variation for seedling vigour among Half-sib families in Nothapodytes nimmoniana (Grah.) Mabber: an antitumor drug yielding plant, Journal of Non-Timber Forest Products, 15(3): 161-165.

Kopp, B., Bauer, W.P. and Schnurch, B. A. (1992). Analysis of some Malaysian dart poisons, Journal of Ethnopharmacology, 36(1): 57-62.

Mirgal, A.B., A.D. Rane, R.P. Gunaga, S.S. Narkhede and S.G. Bhave (2013). A Note on stand dynamics of Antiaris toxicaria (Pers.) Lesch., a rare plant of konkan region of Western Ghats. Indian Forester, 139 (12): 1161-1162.

Ravikumar, K. and R.V. Sankar. (2009). Antiaris toxicaria (Moraceae) - a new distributional record to the Eastern Ghats. J. Threatened Taxa, 1(1): 58-59.

Vasudeva, R., Manjunath, L., R.P. Gunaga, Hombe Gowda, H.C., Uma Shaanker, R. and Ganeshaiah, K.N., 2005. Reproductive biology and half-sib family performance for early vigour in White Cedar, Dysoxylum malabaricum Bedd. In: Tewari, V.P. and Srivastava, R.L. (Eds.). Multipurpose trees in the Tropics: Management and Improvement Strategies, pp. 705-711. 